\title{
ANATOMICAL STUDIES ON THE ARTERIAL BLOOD SUPPLY OF THE PRINCIPAL SALIVARY GLANDS IN THE GOAT
}

\author{
El-Gindy, E. M., Farag, F.M.M., Smith, B.J. \& Daghash, S.M.
}

\begin{abstract}
Twenty-eight heads of clinically normal adult goats of both sexes were used to identify the different arteries supplying the principal salivary glands as well as the distribution of those arteries within each of theses glands. A latex injection, corrosion casting and radiographic preparations and tissue clearing procedures were employed. The obtained results had revealed that the parotid salivary gland received its arterial blood supply from from the external carotid, lingual, caudal auricular, superficial temporal, transverse facial and rostral auricular arteries.. The mandibular salivary gland received its main arterial supply through branches from the common carotid, external carotid and lingual arteries. The monsotomatic sublingual salivary gland received its arterial supply through the sublingual artery while The polystomatic one received glandular branches originated either from the lingual artery, the sublingual artery or from the arch between the two lingual arteries.
\end{abstract}

\section{INTRODUCTION}

The arterial blood supply of the principal salivary glands received the attention of many investigators. Kitamura (1970) in some mammals, El-Khaligi (1974) in the camel, Barnwaland / Sinha (1983) in the buffalo,Hossain (1975), Hanai/ Nakajima/ Fujii/. Nakamura/ Okukawa / Tokita (1983) and Shoaib (2004) in the goat, gave a valuable studies in this field .However, the increase in use of the goat as an experimental 
animal as well as in a wide varieties of surgical studies such as in facial reconstruction work necessitate the continuation of the fine description of the vascular pattern of the structures in and near the potential surgical sites

Based upon these needs, the present study was designed to provide an adequate information on the various arteries devoted to vascularization of the principal salivary glands to address the needs of detailed anatomical knowledge both for veterinary practice as well as using goats as experimental animals.

\section{MATERIAL AND METHODS}

Twenty eight normal, clinically healthy adult goats of both sexes weighing approximately $22-30 \mathrm{~kg}$ (50-65lb) were used. The animals were slaughtered on a level with the middle of the neck. The specimens were flushed through both common carotid arteries using 200-500 cc warm $\left(40^{\circ} \mathrm{C}\right)$ heparinized saline $(0.9 \%$ saline $+1000 \mathrm{IU}$ Heparin/liter $)$ until clear saline flowed continually from the external jugular veins. Four methods were used in the study.

\section{1- Latex injection:}

Nine heads were injected with colored red latex by manual injection through the common carotid arteries. The specimens were then placed in a cold room $(5 \circ \mathrm{C})$ for 3-5 days to allow the latex to harden before manual dissection.

\section{2- Corrosion cast:}

Five heads were used for cast preparation usingred colored Batson's No. 17® (Polysciences, Inc., Warrington, PA, USA). The specimens were kept at room temperature $\left(25^{\circ} \mathrm{C}\right)$ for 4 days then corroded in $10 \% \mathrm{KOH}$ for 4-6 weeks.then rinsed with a gentle stream of water to dislodge the digested tissue. 


\section{3- Radiographic preparation:}

Nine heads were injected with the radio-opaque mass. Six specimens were injected with $60 \% \mathrm{~W} / \mathrm{V}$ barium sulphate suspension in distilled water. This suspension was mixed 1:1 with red latex. The three other specimens were injected with a suspension of $75 \mathrm{gm}$ red lead oxide in 150 c.c. latex.. The injected specimens were immersed in fresh $2 \%$ buffered formaldehyde in cold room for at least one week to allow the latex barium mixture to harden.The salivary glands were ther removed and radio graphed using Eklin EDRS Digital Radiographic system at 40 inch distance and small focal spot beam, at $200 \mathrm{~mA}, 65 \mathrm{kv}$ and $2 \mathrm{mAS}$.

\section{4- Tissue clearing:}

Six head were used, four of theses specimens were latex injected and the other two with the cast material. The specimens then fixed in $10 \%$ buffered formaldehyde form one week then dissected and the salivary glands were removed and dehydrated in an ascending ethanol series beginning at $50 \%$. Single changes at $10 \%$ increment were used between 50 and $90 \%$ and with two changes at 5\% intervals at 95 and $100 \%$. At the $70 \%$ and $80 \%$ levels, $1.0 \mathrm{ml}$ of $30 \%$ hydrogen peroxide was added for bleaching. Four days were allowed between each ethanol change .Lastly the specimens were cleared by immersing for four days using, $100 \%$ Methyl salicylate, $100 \%$ ethanol and benzol mixture 1:1 or a mixture of benzyl benzoate and methyl salicylate (3:5).

The nomenclatures used were those adopted by the Nomina Anatomica Veterinaria (2005) as well as by the available literatures. 


\section{RESULTS}

\section{A. Parotid Salivary Gland:}

The parotid salivary gland consistently received branches from the external carotid, lingual, caudal auricular, superficial temporal, transverse facial and rostral auricular arteries.In few specimens, it also received branches from the common carotid, occipital and maxillary arteries as well. All branches supplying the parotid salivary gland entered the gland from its medial surface.

The A.carotis externa (Figs. 1, 2, 3, 4, 5, 7, 8, / 3) provided three to four branches (Figs. 1, 2, 3, 4, 5, 6, 7, 8/ 13) to the medial surface of the middle third and part of the ventral third of the parotid salivary gland. Most commonly, (18 of 28 specimens), the first two of these branches originated from the mandibular angle artery (Fujiwara, 1970), that originated from the lateral wall of the external carotid artery at the level of the caudal auricular artery. However if the latter artery was absent, these two branches arose either individually (6 of 28 specimens) or by a common trunk ( 4 of 28 specimens) from the rostral border of the external carotid artery just dorsal to the origin of the lingual artery. Anyhow their origin the destination area of these two vessels depended upon whether the lingual artery also participated in supplying the ventral half of the parotid gland or not. If the lingual artery did these vessels supply the dorsal part of the ventral third of the parotid salivary gland. While in only five specimens the lingual artery did not participate and those two branches supplied the entire ventral third and the origin of the parotid duct.The third branch (Figs. 5, 8/ 13) was a short stout vessel, originating from the external carotid artery just before terminating into maxillary and superficial temporal arteries. This branch divided into four vessels, one ventral, two rostral and one caudal, distributed to the middle third of the parotid salivary gland while, the fourth of these branches present in only 3 specimens and originated just caudal to the previous branch, and shared in the supply of the dorsal part of the middle third of the gland. 
The A.lingualis (Figs. 1, 2, 3, 4, 5, 7, 8, / 4) supplied the lower part of the ventral third of the parotid salivary gland in (23 of 28 spceimens). A single stout vessel (Figs. 2, 3, 4, 7, 8, / 14) arising from the lateral wall of the lingual arery just after its origin from the external carotid artery.It proceeded caudally releasing fine collateral rami into the middle part of the mandibular salivary then terminated into the lower part of the ventral third of the parotid salivary gland. In addition to the later main branch, the lingual artery usually detached also 1-2 smaller branches (Figs. 1, 3/ 14) supplying the ventral part of the parotid salivary gland.

The A. auricularis caudalis: (Figs. 1,2,3,4,5,6,7,8/7) supplied three to five glandular branchse(Figs1,2,3,4,5,6,7,8/ 15). These branches originated from both the main stem of the caudal auricular artery as well as its the lateral auricular branch (Figs. 1,2,3,4,5,6,7,8/ 8). The glandular branches arising from former vessel ramified in the dorsal and middle thirds of the parotid salivary gland,while those of the later vessel (Figs. $1,2,3,4,5,6,7,8 / 16)$ supplied the caudodorsal angle of the parotid salivary gland.

The A. temporalis superficialis (Figs. 1,2,3,4,5,6,7,8/9) gave two to four branches (Figs. 1,2,3,4,5,6,7,8/17) to vascularise the rostral part of the middle portion of the dorsal third of the parotid salivary gland.

The A. transversa faciei (Figs. 1,2,3,4,5,6,7,8/ 10) contributed to the arterial supply of the parotid salivary gland through indirect glandular branches arising from the vessels devoted to vascularise the masseter muscle. These branches where represented by two dorsal branches (Figs. 1,2,3,4,5,6,7,8/18) that distributed to the rostral part of the dorsal third of the parotid gland and a third ventral one (Fig. 8/ 18) supplying the rostral border of the gland. 
The A. auricularis rostralis (Figs. 1,2,3,4,5,6,7,8/ 11) supplied two large branches (Figs. 1,2,3,4,5,6,7,8/19) to the upper middle part of the dorsal third of the parotid.

The A.maxillaries (Figs. 1,2,3,4,5,6,7,8/ 12) shared in arterial supply of the parotid salivary gland in only five specimens In four of these specimens, the maxillary artery gave a single either dorsal or ventral branch (Figs. 1,2/ 22) to the rostral part of the dorsal third of the gland, while in the remaining specimen, the later two rami were given (Fig. 7/ 22) to the dorsorostral part of the middle third of the parotid salivary gland.

The A.occipitalis (Figs. 1,2,3,4,5,7,8/ 2) shared in supplying the parotid gland in only seven specimens through a dorsal branch (Figs. 1, $3,4,5,7, / 21)$ that entered the parotid salivary gland from its caudal border of the middle third .

The A.carotis communis (Figs. 1,2,3,4,5, 7,8/ 1) participated in the vascularization of the parotid gland in only three specimens through a single vessel (Figs. 1, 2, 3, 5/ 20) which mainly distributed to the mandibular salivary gland, but extended beyond it to supply the ventral extremity of the parotid salivary gland as well.

\section{B. Mandibular Salivary Gland:}

Twenty-four mandibular salivary gland specimens were examined to describe the arterial supply of the gland. It recieved its main arterial supply through branches from the common carotid, external carotid and lingual arteries and in few specimens also from the occipital artery .

The A. carotis communis (Figs. 3, 4, 8, 9, / 1) shared in supplying the mandibular gland in only forteen of the examined specimens through 1-2 mandibular branches (Figs. 3, 4, 8, 9/23) which distributed to the ventral border of the middle third of the mandibular salivary gland. 
The A. carotis externa (Figs. 3, 4, 8, 9/ 3) provided a single large mandibular branch (Figs. 4, 8, 9/24) to the caudal part of the mandibular salivary gland. This branch either arose either directly from the rostral or medial wall of the external carotid artery, just dorsal to the origin of the lingual artery, or indirectly from a large masstereric branch . It proceeded ventrally to reach the dorsal border of the mandibular salivary gland. Upon entering the gland, the artery broke into three to four branches that distributed in the caudal part of the gland.

The A. lingualis (Figs. 4, 8, 9/4) provided the main arterial source of the mandibular salivary gland. It detached two main mandibular branches (Figs. . 4, 8, 9/ 25) from its medial or dorsal walls. Those glandular branches enter the mandibular salivary gland from its dorsal border, and supplied most of the its rostral and middle regions.

The A. occipitalis(Figs. . 4, 8, 9/2) shared in the arterial supply of the mandibular salivary gland, in only five specimens through small branch (Figs. 8, 9/26) arising from its ventral wall near its origin and supplying the caudal border of the gland.

\section{Sublingual Salivary Gland:}

Sixteen specimens of the sublingual salivary gland were studied to determine the arterial supply of the gland.

The monsotomatic gland received its arterial supply through the A.Sublingualis (Figs. 11/6) which detaced four to five branches (Figs. 10/ 28) from its lateral or dorsal walls. Those branches entered the gland from its ventral border and proceeded dorsally within the gland.

The polystomatic gland received a single glandular branch (Figs. $10 / 27$ ) arising from either the lingual artery (12 of 16 specimen) or the sublingual artery (3 of 16 specimens), while in one other specimens arose 
from the arch formed in between the two lingual arteries. In the most common pattern, this glandular branch entered the gland from its caudal border and split into a dorsal and a ventral branch that distributed inside the gland. However. In three specimens the later two rami were detached independently,from the lingual artery.

\section{DISCUSSION}

The varieties of the glandular branches devoted to vascularize the parotid salivary gland in the goat were similar to those reported by different authors among various domestic animals. Those arising the external carotid, caudal auricular and superficial temporal arteries were also reported by Habel (1975) in domestic ruminants, May (1970) in the sheep, Kitamura (1970), Hossain (1975), Hanai et al. (1983) and Shoaib (2004) in the goat, El-khaligi (1974) and Kassab (1997) in the camel, Sisson (1975) in the horse and Attia (1982) in the mule. On the other hand the latter rami were not observed by Heeschen (1958) and Schwarz (1959) in the small ruminants. It is to add also that parotid glandular branches given by the external carotid artery were also did not mentioned by Kitamura (1970) in the goat.

The present work showed that the parotid branches originating from the rostral auricular and transverse facial arteries were similarly mentioned by Attia (1982) in the mule and Hossain (1975), Hanai et al (1983) and Shoaib (2004) in the goat, while those originating from the lingual artery were also reported by Heeschen (1958) and Schwarz (1959) in small ruminants and Hanai et al. (1983) and Shoaib (2004) in the goat.

The mandibular angle artery in the present work was reported by Fujiwara (1970) in the goat and was similar to the parotido-mandibular artery reported by Barnwal and Sinha (1983) in the buffalo and Shoaib 
(2004) in the goat. The other less frequent branches reported in this study that originated from the common carotid, occipital and maxillary arteries were not reported by any other author among various domestic animals.

The current investigation have shown that the lingual artery represented the main source for the arterial supply of the mandibular salivary gland. Simliar finding was reported by Habel (1975) and Wilkens and Münster (1981) in ruminants, May (1970) and Molenda (1973) in the sheep and Takashima (1967), Hossain (1975) and Shoaib (2004) in the goat.

It might be added that, the single mandibular glandular branch arising from the external carotid artery in the present work was also the reported by Raghavan and Kashroo (1964) in the ox, Molenda (1973) in the sheep, El-Khaligi (1974) in the camel, Barnwal and Sinha (1983) in the buffalo. This branch could be favourably matched with the parotidomandibular artery recorded by Takashima (1967) and Shoaib (2004) in the goat.

The present work recorded the little and rare contribution of the occipital artery in supplying the mandibular salivary gland. Similar observations were also stated by Raghavan and Kashroo (1964) in the ox, Molenda (1973) in the sheep, El-Khaligi (1974) in the camel and Takashima (1967) and Hossain (1975) in the goat.

The present study also revealed the participation of the common carotid artery in supplying the mandibular salivary gland , an observation which was recorded before only by Barnwal and Sinha (1983) in the buffalo. However The latter authors described such participation as a minor arterial supply to the gland. On the other hand non of the available literatures recorded any share of the common carotid artery in supplying the mandibular salivary gland neither in the goat nor any other small ruminant. 
The present invetigations as well as those given by Hossain (1975) and Shoaib (2004) in the goat, May (1970) in the sheep, McLeod (1958) in the ox, El-Gaafary (1964) and Barnwal and Sinha (1983) in the buffalo, El-Khaligi (1974) in the camel and Attia (1982) in the mule recorded that the sublingual salivary gland both monostomatic and polystomatic were vascularized through glandular branches arising from the lingual and sublingual arteries to the sublingual salivary gland observed in the present work were commonly reported among various domestic animals as reported by. However, Raghavan and Kashroo (1964) in the ox, Habel (1975) in domestic ruminants, Sisson (1975) in the horse, and Attia (1982) in the mule mentioned that the arterial supply of the gland was derived only from the sublingual artery without sharing of the lingual artery.

\begin{tabular}{|c|c|c|c|}
\hline \multicolumn{4}{|c|}{ Legends for figures (1-10) } \\
\hline $1-$ & A.carotis communis. & $15-$ & Parotid branches of 7 \\
\hline $2-$ & A.occipitalis. & $16-$ & Parotid branches of 8 \\
\hline $3-$ & A.carotis externa. & $17-$ & Parotid branches of 9 \\
\hline 4- & A.lingualis. & $18-$ & Parotid branches of 10 \\
\hline $5-$ & A.profuda linguae. & $19-$ & Parotid branches of 11 \\
\hline 6- & A. Sublingualis. & $20-$ & Parotid branches of 1 \\
\hline 7- & A. auricularis Caudalis. & $21-$ & Parotid branches of 2 \\
\hline 8- & Ramus auricularis lateralis & |22- & Parotid branches of 12 \\
\hline 9- & A.temporalis superficialis & $23-$ & Mandibular brances. of 1 \\
\hline $10-$ & A.transversa faceie. & $24-$ & Mandibular branch of 3 \\
\hline $11-$ & A.auricularis rostralis. & $25-$ & Mandibular branches of 4 \\
\hline $12-$ & A.maxillaris. & $26-$ & Mandibular branch of 2 \\
\hline $13-$ & Parotid branches of 3 & $27-$ & Sublingual branches of 4 \\
\hline $14-$ & Parotid branches of 4 & $28-$ & Sublingual branches of 6 \\
\hline
\end{tabular}

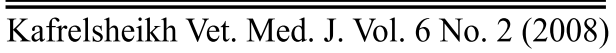




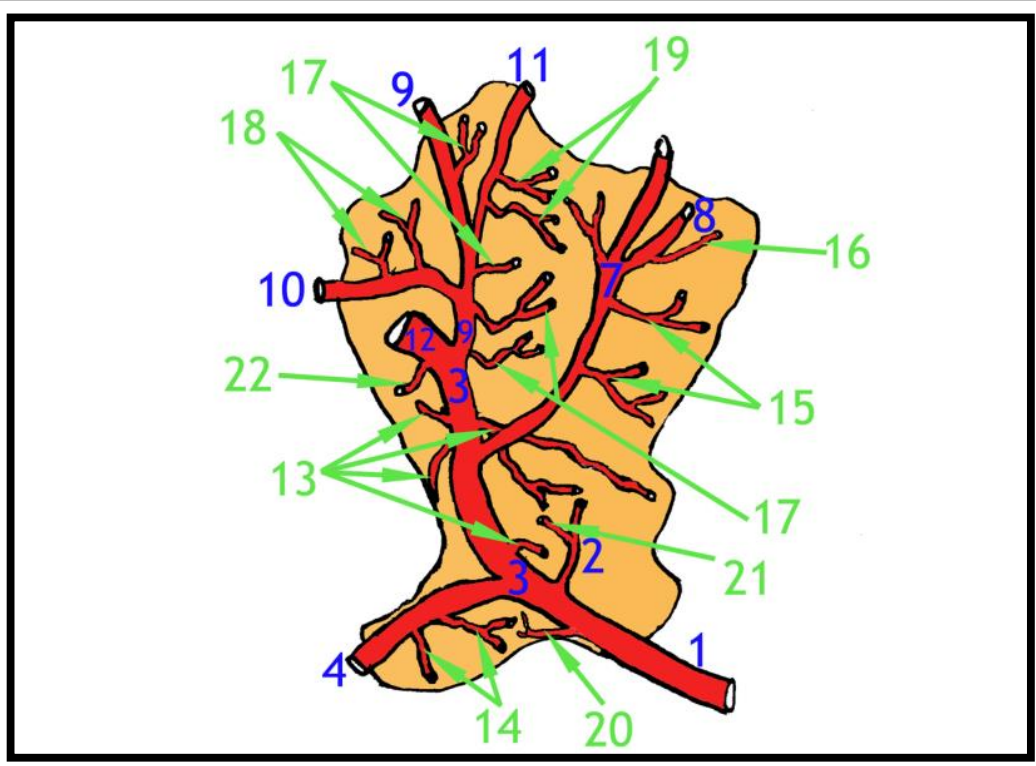

Fig. (1): Diagram of the parotid salivary gland of the goat showing the arterial distribution inside the gland 383-394.

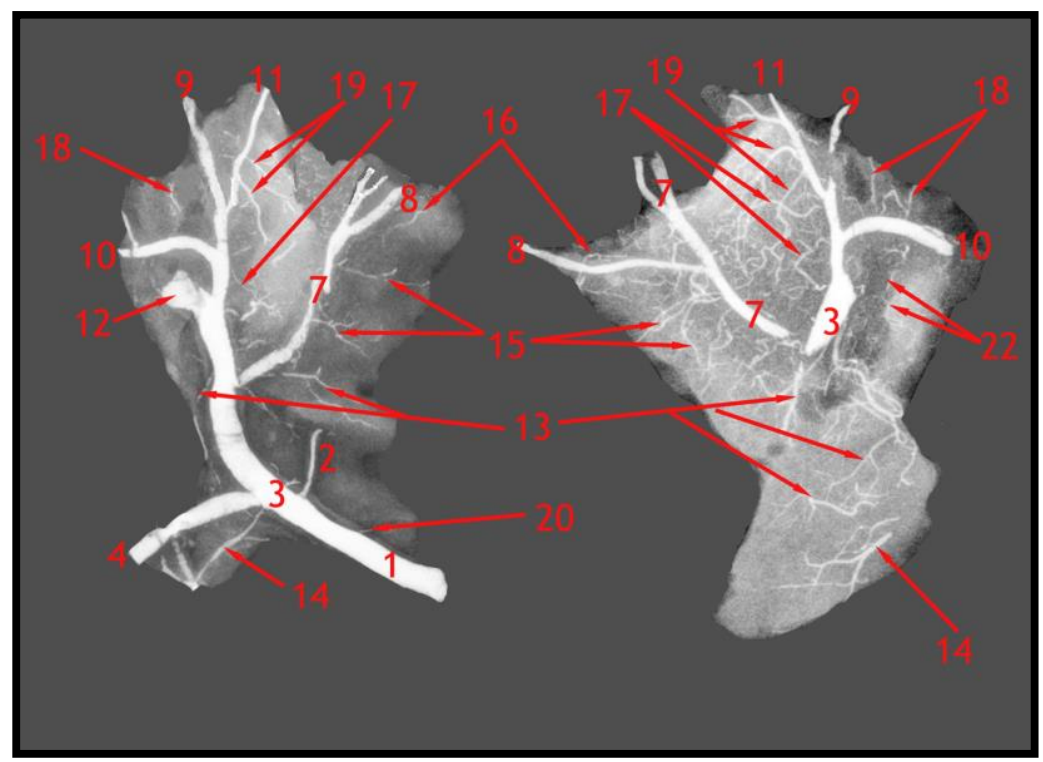

Fig. (2): Radiographs of barium injected parotid salivary glands of the goat showing the arterial distribution inside the glands. 
El-Gindy, E. M et al.,

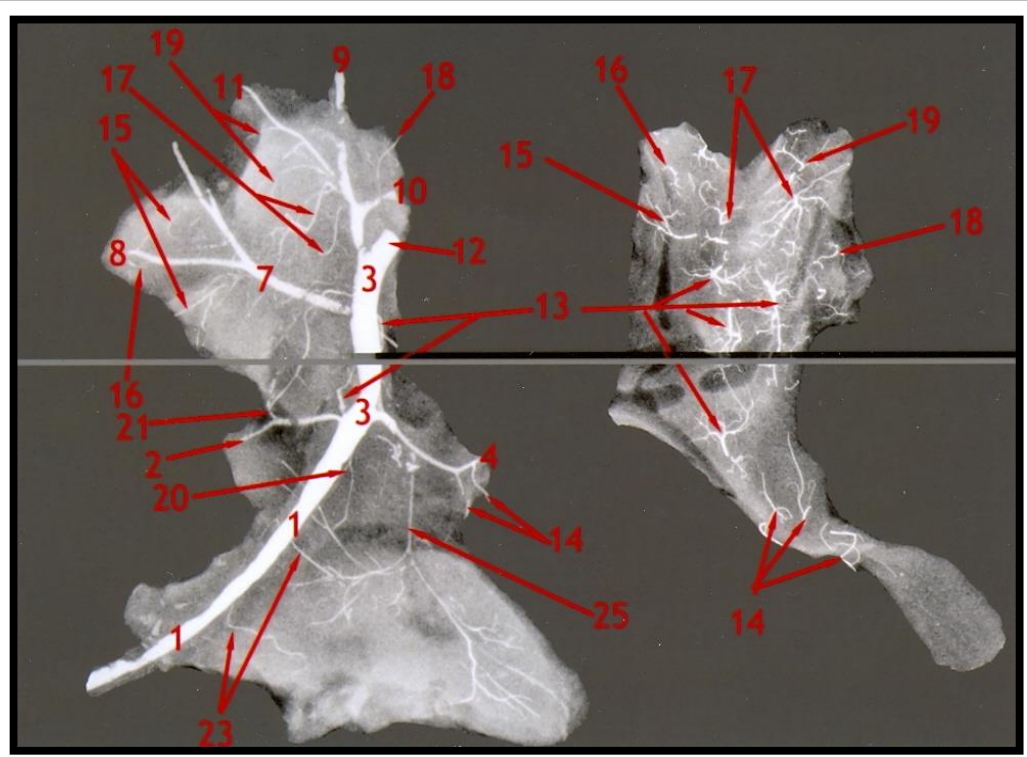

Fig. (3): Radiographs of lead oxide injected parotid salivary glands of the goat showing the arterial distribution inside the glands. Using an Eklin EDRS Digital Radiographic system at 40 inch distance and small focal spot beam, at $200 \mathrm{~mA}, 65 \mathrm{kv}$ and $2 \mathrm{mAS}$.

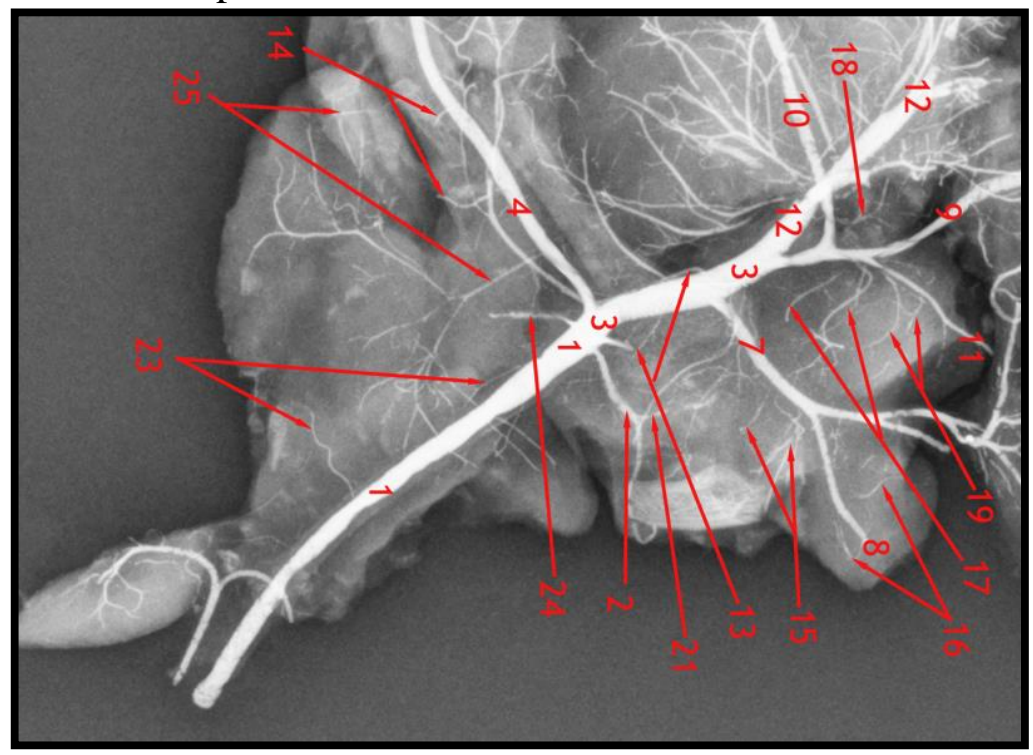

$\overline{\text { Kafrelsheikh Vet. Med. J. Vol. } 6 \text { No. } 2 \text { (2008) }}$ 
Fig. (4): Radiographs of barium injected parotid and mandibular salivary glands of the goat showing the arterial distribution inside the glands.

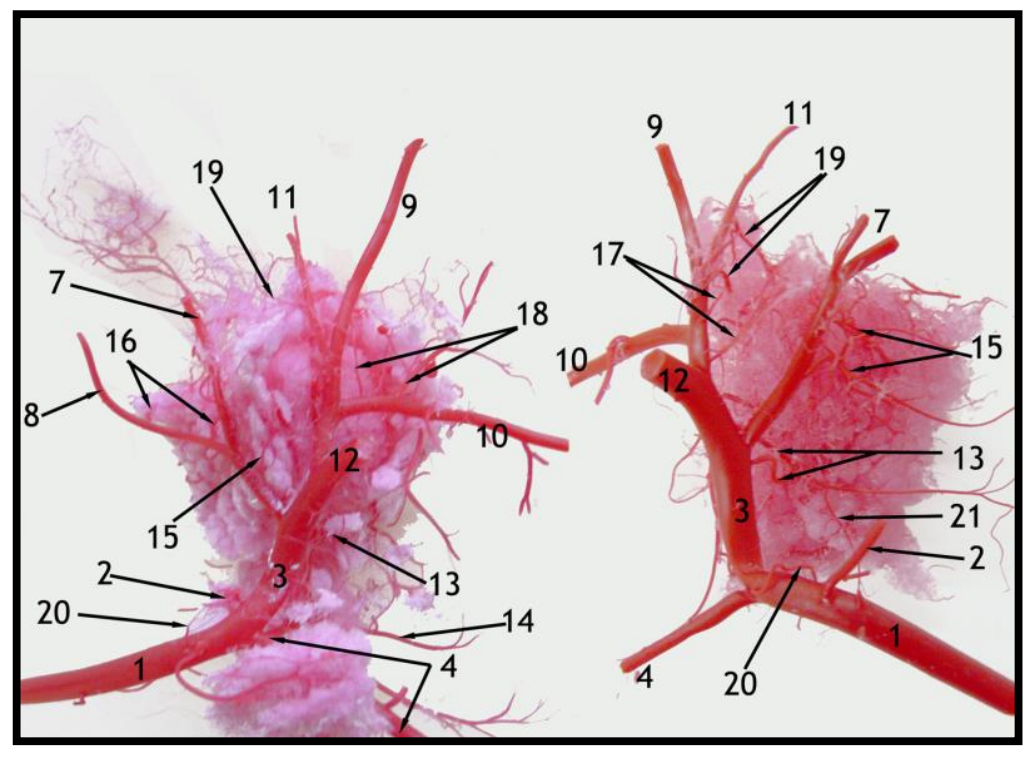

Fig. (5): Medial (left) and medio-caudal (right) views of Batson's No. 17 cast of the parotid salivary glands of the goat showing the arterial distribution inside the glands

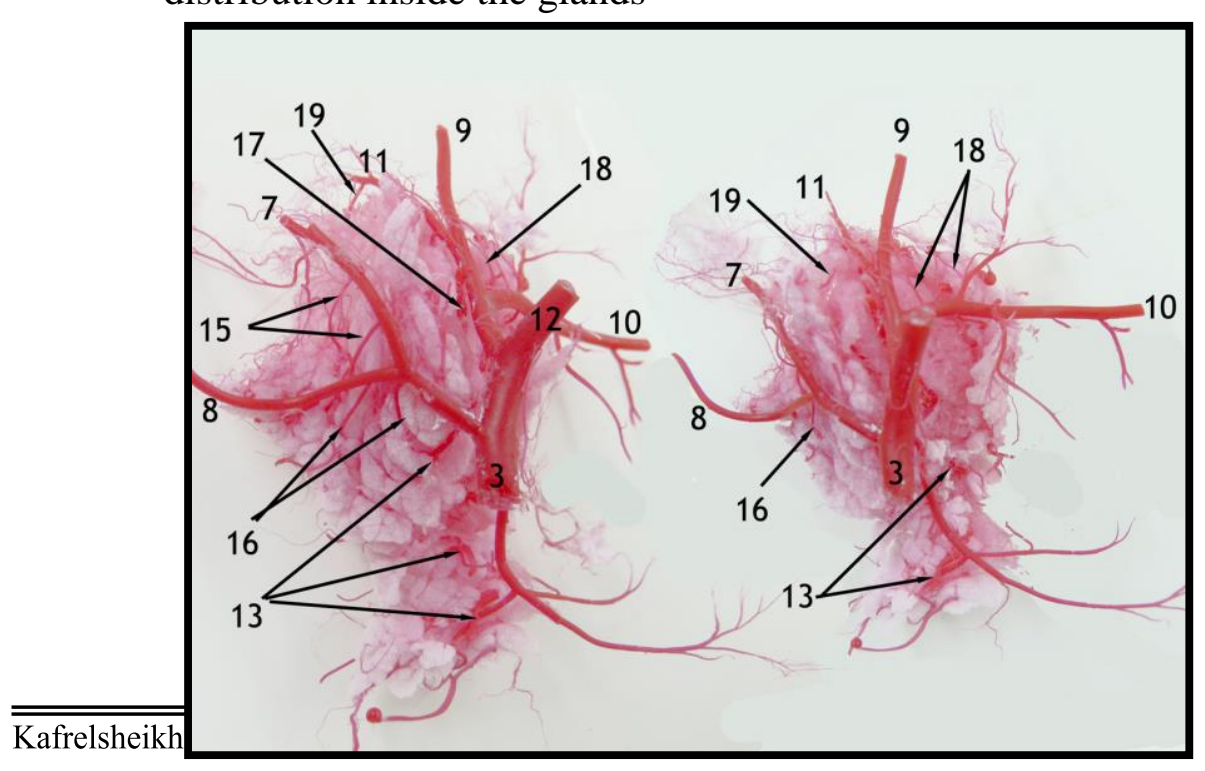


Fig. (6): Medial (right) and medio-caudal (left) views of Batson's No. 17 cast of the parotid salivary gland of the goat showing the arterial distribution inside the gland.

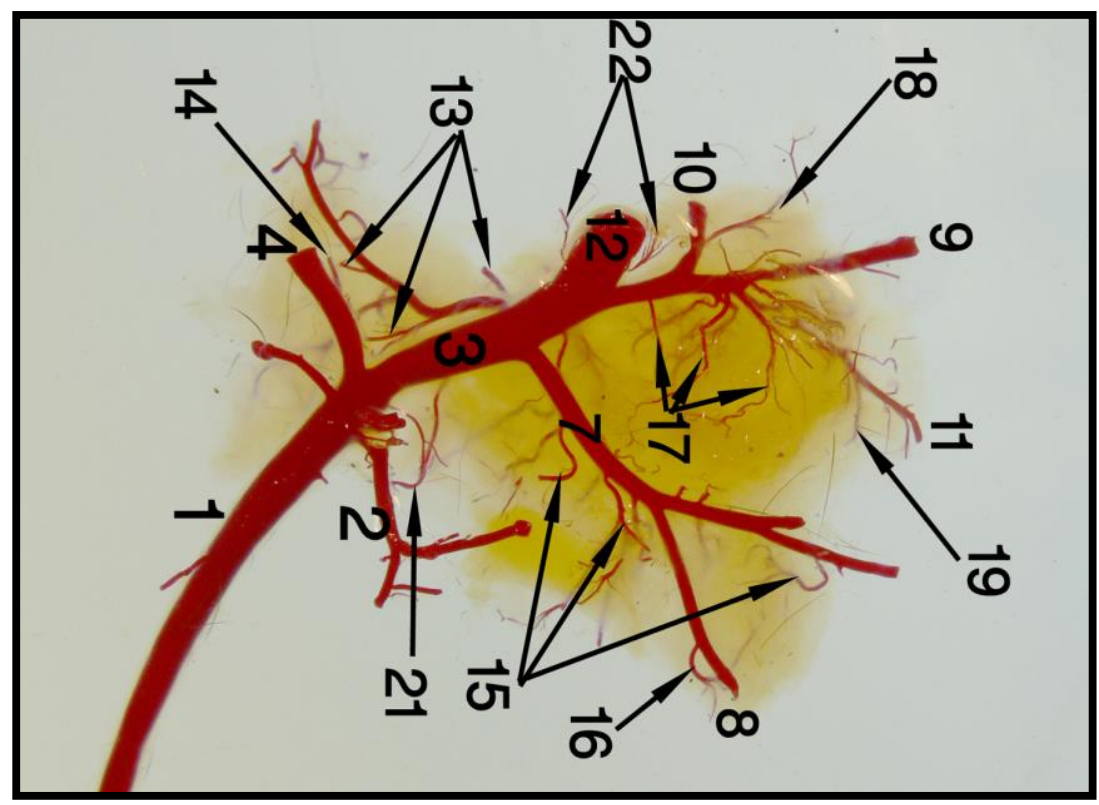

Fig. (7): Medial view of cleared latex injected parotid salivary gland of the goat showing the arterial distribution inside the gland

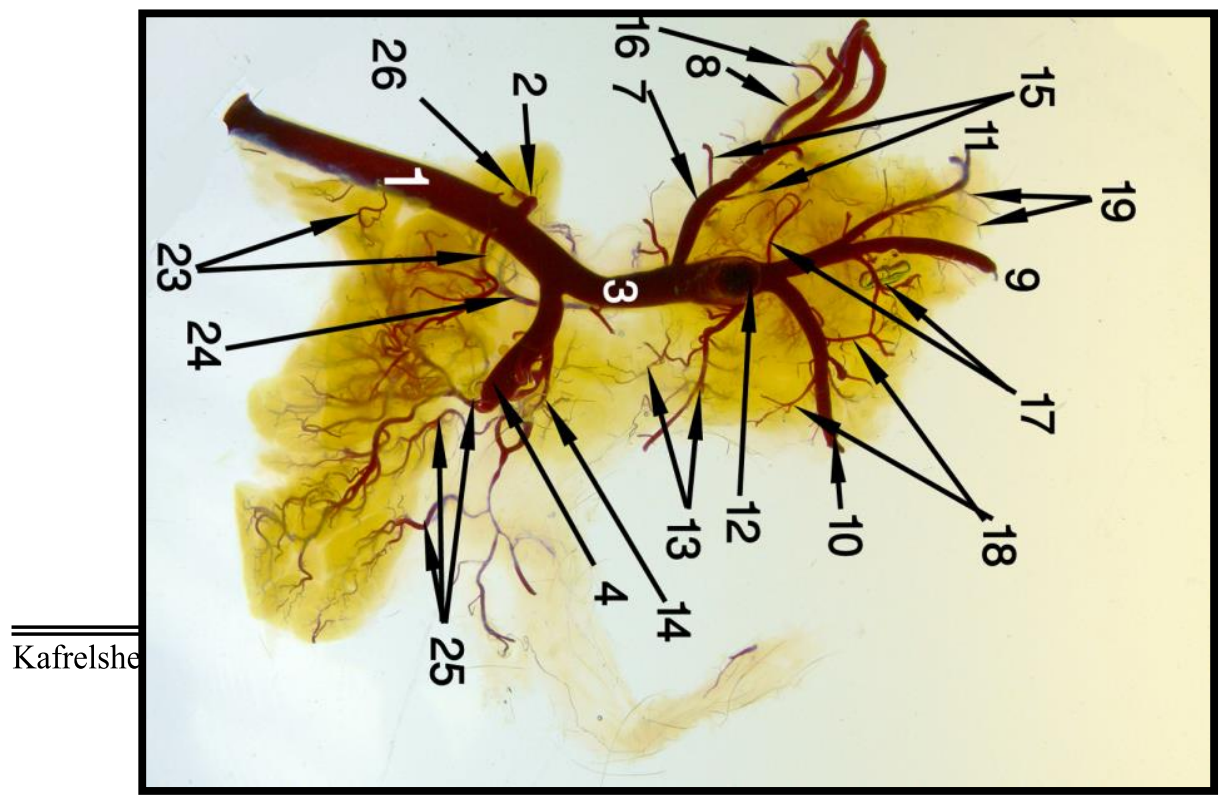


Fig. (8): Medial view of cleared latex injected parotid and mandibular salivary glands of the goat showing the arterial distribution inside the glands.

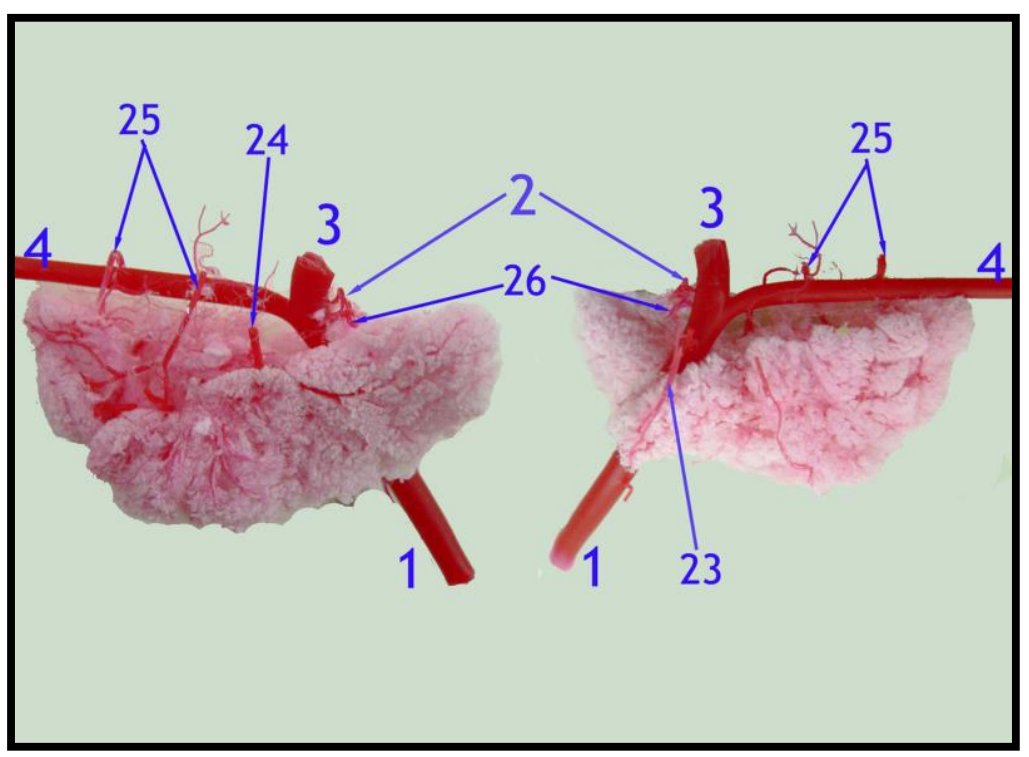

Fig. (9): Medial (right) and lateral (left) views of Batson's No. 17 cast of the mandibular salivary gland of the goat showing the arterial distribution inside the gland.

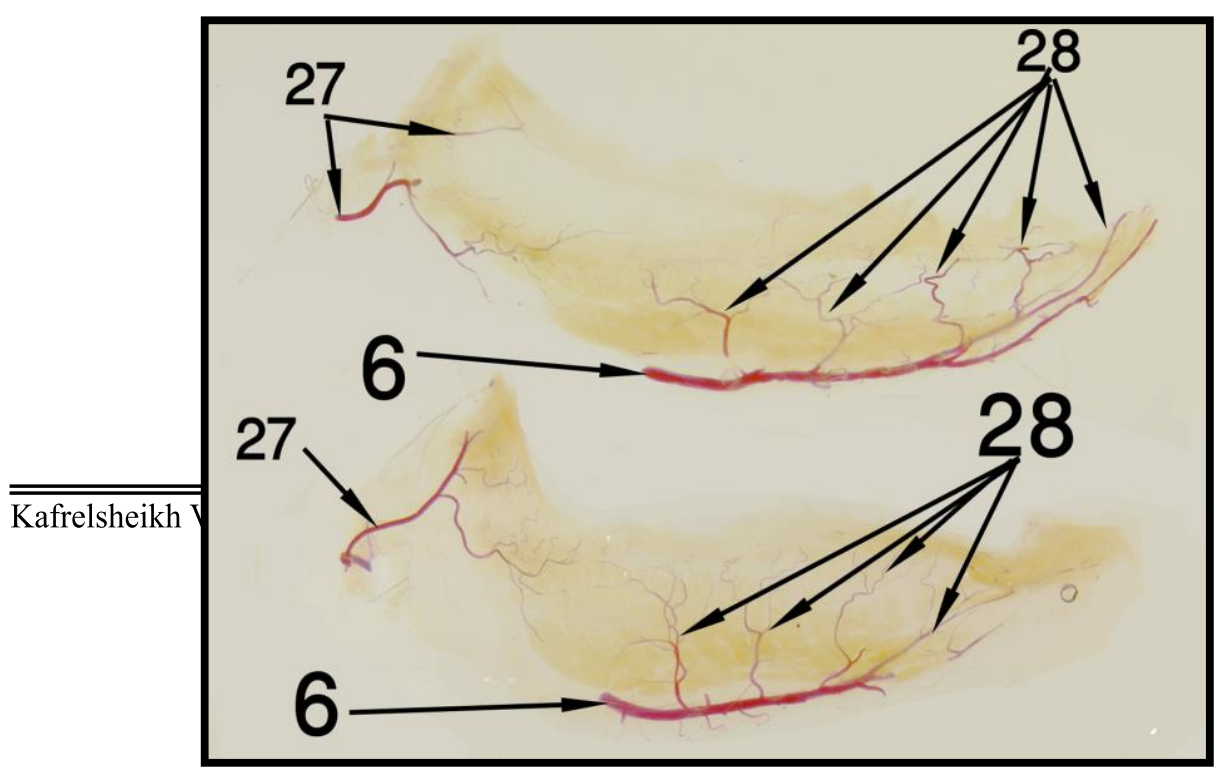


Fig. (10): Cleared latex injected sublingual salivary glands of the goat showing the arterial distribution inside the glands

\section{REFERENCES}

- Attia, M. (1982): Arteries and veins of the head and neck of the mule (Equus hinnus). Ph. D. Thesis, Faculty of Veterinary Medicine, Assuit University. Egypt.

- Barnwal, A.K. and R.D. Sinha (1983): Anatomical studies on the blood supply of the salivary glands of buffalo. The Indian Journal of Animal Sciences, 53 (5): 503-507.

- El-Gaafary, M.A. (1964): A study of the gross and microscopic anatomy of the glandular and lymphoid tissues in the head region of the Egyptian buffalo. M. D. (Vet) Thesis, Faculty of Veterinary Medicine, Cairo University, Egypt.

- El-Khaligi, G.E.M. (1974): Anatomical and histological studies on some of the salivary glands of the One-humped camel. M.V.Sc. Thesis, Faculty of Veterinary Medicine, Cairo University, Egypt. 
- Fujiwara, I. (1970): Stereological studies on several ducts and vessels by injection method of acrylic resin. XXVII. Arterial distribution of the masseter muscle in some mammals. Okajimas Folia Anatomica Japonica, 47 (5): 335-352.

- Habel, R.E. (1975): Ruminant digestive system in Getty, R.: Sisson and Grosman's - The anatomy of the domestic animals, 5th edition, vol. I. W. B. Saunders Company, Philadelphia. London.

- Hanai, H.; T. Nakajima, H. Fujii, T. Nakamura, J. Okukawa and N. Tokita (1983): On the arterial distribution of the goat parotid gland. Josai Shika Daigaku Kiyo, 12 (3): 309-315.

- Heeschen, W. (1958): Arterien und Venen am kopf des Schafes. Dissertation (Med.Vet.), Hannover.

- Hossain, M.I. (1975): The arterial supply to the salivary gland of Black Bengal goat. Indian Veterinary Journal, 52: 699-702.

- Kassab, A.A.M. (1997): Comparative anatomical studies on the external ear of the camel (Camelus dromedarius) and donkey (Equus asinus). M.V.Sc. Thesis, Benha faculty of Veterinary Medicine, Zagazig University, Egypt.

- Kitamura, H. (1970): Stereological studies on several ducts and vessels by injection method of acrylic resin. XXVI. 
Arterial distribution of the Parotid Gland in some mammals. Okajimas Folia Anatomica Japonica, 47: 319-333.

- May, N.D.S. (1970): The antomy of the sheep. $3^{\text {rd }}$ edition, University of Queensland Press.

- McLeod, W.M. (1958): Bovine Anatomy, $2^{\text {nd }}$ edition, BurgessPublishing Company, Minneapolis.

- Molenda, O. (1973): Arteries supplying the mandibular gland in sheep. Folia Morphologica (Warsz.), 32(2): 185-193.

- Nomina Anatomica Veterinaria (2005): $5^{\text {th }}$ edition. Prepared by the international Committee on Veterinary Gross Anatomical Nomencla-ture (I.C.V.G.A.N) and authorized by the General Assembly of the World Association of Veterinary Anatomists (W.A.V.A.), Knoxville, TN (USA). Published by the Editorial Committee, Hannover, Columbia, Gent, Sapporo.(Electronic version).

- Raghavan, D. and P. Kachroo (1964): Anatomy of the ox with comparative notes on horse, dog and fowl. $1^{\text {st }}$ edition. Indian council of Agricultural Research, New Delhi, India.

- Schwarz, R. (1959): Arterien und Venen am kopf der Ziege. Dissertation (Vet. Med.), Hannover. 
- Shoaib, M. M. A. (2004): Some anatomical studies on the salivary glands of the goat. Ph.D. Thesis, Faculty of Veterinary Medicine, Zagazig University, Egypt.

- Sisson, S. (1975): Equine digestive system in Getty, R.: Sisson and Grosman's - The anatomy of the domestic animals. $5^{\text {th }}$ edition, vol. I \& II, W. B. Saunders Company, Philadelphia. London.

- Takashima, T. (1967): Sterological studies on several ducts and vessels by injection method of acrylic resin. XIX. Arterial distribution of the submandibular gland in some mammals. Okajimas Folia Anat. Jpn., 43: 363-383.

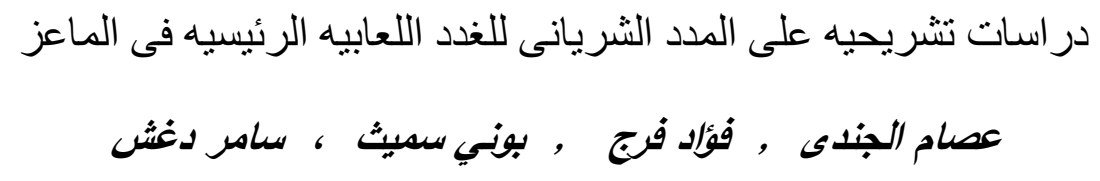

اجرى البحث على28 راس ماعز بالغه من الجنسين و سليمه اكلينيكيا. . وقد نم حقن تسع منها بالمطاط السائلا ؛كما تم حقن عشر منها بكتله عمل القوالب ا لملون المكون من باتسون رقم 17؛ أما باقى العينات فقد نم حقنها بالكتله الظليله على الاتشعاع المكون من كبريتات الباريوم (6 عينات ) او اكسيد الرصاص الاحمر (3عينات) ثم تم تعرضت للاشعاع باستخدام

Eklin EDRS Digital Radiographic system at 40 inch distance and small focal spot beam, at $200 \mathrm{~mA}, 65 \mathrm{kv}$ and $2 \mathrm{mAS}$. 
ولوصف توزيع الثرايين داخل الغدد اللعابيه تم عمل طريقه اظهار النسيج حيث

يتحول النسيج المحقون الى نسيج شبه شفاف ليظهر ما بداخله وتبدأ (Tissue clearing procedure) هذه الطريقة بحقن السائل المطاط او المادة المستخدمة لعمل القوالب، ثم تغمر العينات فى السوائل المسبته، ثم التشريح والتجفيف والإظهار •

وقد بينت الدراسة أن الددد الثريانى للغده النكفيه ياتى عن طريق الشريان السباتى الخارجى

بثلاث أو أربعه فروع؛ الثريان اللسانى يغذى الجزء الأدنى من الثلث السفلى من الغده النكفيه وأن الثريان الاذنى الخلفى يعطى ثلاثة الى خمسه وفى بعض الاحيان سبعه فروع للأجزاء الخلفية من الجزء العلوى و الاوسط للغده النكفيه.كما وضحت الدراسه ان كل من الثريان السطحى الصدغى و الوجهى المستعرض و الاذنى الامامى و الفكى العلوى يشارك فى تغذيه الغده النكفيه فى حين تكون مشاركه الثريان القوى و السباتى العام نادره و قليله.

المدد الثريانى للغده الفكيه يأتى عن طريق الثريان السباتى العام الذى يغذى الجزء الاوسط من الغذه بواسطه فرع أو فرعين. أما الثريان السباتى الخارجى فيعطى فرع واحد كبير للجزء الخلفى من الغده.أما الثريان اللسانى فيمد الغده بالمدد الثريانى الرئيسى فى حين ان الثريان القفوى نادرا ما يغذى

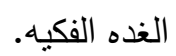

الغده تحت اللسانيه وحيده الثغر تنتمد مددها الثريانى من الثريان تحت اللسانى بواسطه اربعه او خمسه فروع • فى حين أن الغده تحت اللسانيه عديده الثغور فتستمد مددها الثريانى بواسطه الثريان اللسانى فى معظم الحالات ومن الثريان تحت اللسانى فى حالات اقل وقد تم مناقثنه النتائج التى تم 
الحصول عليها مع مثيلتها في بعض الأبحاث السابقة المتاولة وقد استخدمت المسميات وفقا لما ورد

.N.A.V. (2005) 